\title{
Effects of allergy and age on responses to salbutamol and ipratropium bromide in moderate asthma and chronic bronchitis
}

\author{
C P van Schayck, H Folgering, H Harbers, K L Maas, C van Weel
}

Department of General Practice and Family Medicine C P van Schayck H Harbers K L Maas $C$ van Weel

Department of Pulmonary Diseases H Folgering

Nijmegen University, PO Box 9101, $6500 \mathrm{HB}$ Nijmegen, The Netherlands

Reprint requests to: Dr van Schayck

Accepted 31 January 1991

\begin{abstract}
The bronchodilating responses to $400 \mu \mathrm{g}$ salbutamol and $80 \mu \mathrm{g}$ ipratropium bromide were studied in 188 patients with chronic bronchitis $(n=113)$ or asthma $(n=75)$ and mild to moderate airflow obstruction (forced expiratory volume in one second $\left(F E V_{1}\right)$ above $50 \%$ but below 2 SD of predicted value) in a crossover study on two days a week apart. Both the patients with asthma and the patients with chronic bronchitis varied considerably in their responses to the salbutamol and the ipratropium bromide. The mean increase in $\mathrm{FEV}_{1}$ in the subjects with asthma was higher after salbutamol $(0.371$ or $18 \%$ of the prebronchodilator value) than after ipratropium bromide $(0.261$ or $13 \%)$. In chronic bronchitis there was no difference between the increase in $F E V_{1}$ after salbutamol $(0 \cdot 161$ or $7 \%)$ and after ipratropium bromide $(0.191$ or $8 \%)$. When patients were categorised into those with a better response to salbutamol $400 \mu \mathrm{g}$ and those with a better response to ipratropium bromide $80 \mu \mathrm{g}$, patients with chronic bronchitis responded better in general to ipratropium bromide whereas asthmatic patients responded better to salbutamol. The response pattern was also related to allergy and age, allergic patients and patients under 60 being more likely to respond better to salbutamol $400 \mu \mathrm{g}$ than nonallergic patients and older patients, who benefited more from ipratropium bromide $80 \mu \mathrm{g}$. The response pattern was not related to sex, smoking habits, lung function, bronchial reactivity, respiratory symptoms, or number of exacerbations during the preceding year.
\end{abstract}

salbutamol $400 \mu \mathrm{g}$ and ipratropium bromide $80 \mu \mathrm{g}$ in 188 patients with mild to moderate airflow obstruction selected from general practice. The aim of the study was to investigate the $\mathrm{FEV}_{1}$ response to these doses of salbutamol and ipratropium bromide in patients with asthma or chronic bronchitis and to relate the response to the clinical characteristics of the patients.

\section{Methods}

The current study was part of an intervention study, designed to assess the long term effects of bronchodilator treatment in patients with asthma and chronic bronchitis. ${ }^{4}$ One hundred and eighty eight patients of 30 years and over with mild to moderate airflow obstruction were recruited from 29 general practices. $F E V_{1}$ had to be two standard deviations below their FEV $_{1} \%$ predicted value ${ }^{5}$ but above $50 \%$.

All subjects had participated in the intervention study for 12 months before the current study was carried out.

\section{PATIENTS}

One hundred and thirteen patients with chronic bronchitis and 75 patients with asthma were included in the study (table 1). The criteria for the diagnosis of chronic bronchitis and asthma were based on those of the American Thoracic Society. ${ }^{6}$ Patients were diagnosed by assessing symptoms (Medical Research Council (MRC)-European Community for Coal and Steel (ECCS) questionnaire), lung function (before and 60 minutes after $400 \mu \mathrm{g}$ salbutamol and $80 \mu \mathrm{g}$ ipratropium bromide), and bronchial reactivity one week and six and 12 months before the start of the current crossover study. Chronic bronchitis was defined as persistent bronchial obstruction $\left(\mathrm{FEV}_{1} \leqslant 85 \%\right.$ of the predicted value for all measurements) combined with chronic cough or chronic sputum production during at least three months for at least two consecutive years.

Although the bronchodilating effects of

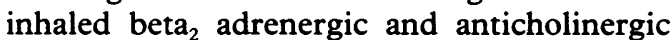
drugs have been widely studied in patients with asthma and chronic bronchitis, few studies have compared the $\mathrm{FEV}_{1}$ response to the two drugs in the same patients. ${ }^{1-3}$ The three studies that have done so looked at a small number of patients referred for specialist treatment so it is difficult to known how generally applicable the findings are. The small numbers also make it difficult to relate the bronchodilator responses to the clinical characteristics of the patients. The current study assessed the bronchodilator response to 
Table 1 Clinical characteristics of the patients with chronic bronchitis and asthma

\begin{tabular}{llll}
\hline & $\begin{array}{l}\text { Chronic } \\
\text { bronchitis }\end{array}$ & Asthma & Total \\
\hline Number & 113 & 75 & 188 \\
Age (mean (SD) y) & $53(13)$ & $51(13)$ & $52(13)$ \\
Sex (\% male) & $62^{\star}$ & 47 & 56 \\
Smokers (\%) & $88^{\star \star}$ & 71 & 81 \\
Pack years (mean No) & $19^{\star \star}$ & 13 & 16 \\
Allergic (\%) & $18^{\star \star}$ & 35 & 24 \\
Symptom score (mean (SD)) & $4 \cdot 9(1 \cdot 8)$ & $5 \cdot 1(1 \cdot 7)$ & $5 \cdot 0(1 \cdot 8)$ \\
Exacerbations (mean (SD) No) & $1 \cdot 1(2 \cdot 1)^{\star}$ & $1 \cdot 6(2 \cdot 5)$ & $1 \cdot 3(2 \cdot 2)$ \\
Lung function (mean (SD)) & & & \\
FEV $(1)$ & $2 \cdot 39(0 \cdot 79)^{\star}$ & $2 \cdot 13(0 \cdot 73)$ & $2 \cdot 29(0 \cdot 77)$ \\
FEV $\%$ pred & $76(18)$ & $71(21)$ & $74(19)$ \\
FEV $_{1} /$ IVC (\%) & $68(10)^{\star \star}$ & $63(11)$ & $66(11)$ \\
FEV $_{1} /$ IVC \% pred & $84(12)^{\star \star}$ & $76(12)$ & $81(12)$ \\
Geometric mean PC $_{20}(\mathrm{mg} / \mathrm{ml})$ & $20^{\star \star \star}$ & 5 & 14 \\
\hline
\end{tabular}

${ }^{\star} \mathrm{p}<0.05 ;{ }^{\star \star} \mathrm{p}<0.01 ;{ }^{\star \star \star} \mathrm{p}<0.005$ (differences between asthma and chronic bronchitis compared by the non-paired Student's $t$ test).

STUDY DESIGN

The experiment had a single blind crossover design (blind observer). The bronchodilator responses to salbutamol $400 \mu \mathrm{g}$ and to ipratropium bromide $80 \mu \mathrm{g}$ were assessed on two days: on one day salbutamol was given first and ipratropium bromide second and on the other day the drugs were given in reverse order. The order of the two days was randomised. The drugs were administered at about the same time of day during two consecutive weeks in an exacerbation free period.

During the 12 month intervention study the number of exacerbations was assessed by the general practitioner. An exacerbation was defined according to Fletcher (modification by Boman et $a l^{7}$ ). Lung function and bronchial reactivity were assessed during an exacerbation free period one week and six and 12 months before the start of the study.

MEDICATION DURING THE INTERVENTION STUDY No corticosteroids or bronchodilators other than salbutamol or ipratropium bromide were permitted in the 12 month study. At the start of the intervention study patients were randomly assigned to one of four parallel treatment groups: continuous medication with $4 \times 400$ $\mu \mathrm{g} /$ day salbutamol by dry powder inhaler $(\mathrm{n}=49) ; 4 \times 40 \mu \mathrm{g} /$ day ipratropium bromide by dry powder inhaler $(n=43)$ or symptomatic medication with dry powder inhalations of salbutamol $(n=52)$ or ipratropium bromide $(n=44)$ during exacerbations or periods of dyspnoea. The patients were asked to report the medication used each week. During the study year the symptomatically treated patients used the same number of dry powder inhalations of salbutamol as of ipratropium-a mean of 0.6 (SD 0.8$)$ a day. The medication the patients had used in the preceding year was known, and used to determine whether there was evidence of tolerance to ipratropium bromide or salbutamol.

MEASUREMENTS

$\mathrm{FEV}_{1}$, forced vital capacity (FVC), and inspiratory vital capacity (IVC) were assessed before and 15 minutes after inhalation of $400 \mu \mathrm{g}$ salbutamol and before and 45 minutes after $80 \mu \mathrm{g}$ ipratropium bromide, both given by metered dose inhaler. Data were derived from the curve with the largest sum of FVC and $\mathrm{FEV}_{1}$ (out of three measurements). All bronchodilator medication was discontinued eight hours before the start of the test. $\mathrm{FEV}_{1}$ and FVC were measured by three doctors and two laboratory workers trained in using the Microspiro spirometer HI-298 (Chest Corporation, Tokyo). This spirometer measures instantaneous flow, which is electronically integrated to give volume. ${ }^{8}$ IVC was measured with a wet spirometer (Gould, Bilthoven, The Netherlands).

Bronchial reactivity $\left(\mathrm{PC}_{20}\right)$ was tested by means of a histamine challenge test as described by Cockcroft et al..$^{9}$ Symptoms were assessed by the MRC-ECCS questionnaire (Dutch version $)^{10}$ and quantified by addition to provide a score of $0-8 .{ }^{4}$ Smoking history was assessed in pack years (number of packets of cigarettes smoked daily $\times$ years of smoking). Allergy was tested with seven radioallergosorbent tests (RAST) (pollen: wild flowers, grasses, trees; animals: cats and dogs; house dust mite; Aspergillus fumigatus) (Pharmacia AB, Uppsala, Sweden). Patients were considered to be allergic if at least one RAST response was positive. The allergy response was measured semiquantitatively on a scale ranging from 0 (no response) to 4 (strong response). The scores for all seven tests were added to provide an allergy score. ${ }^{11}$

\section{ANALYSES}

Change in $\mathrm{FEV}_{1}$ in response to $400 \mu \mathrm{g}$ salbutamol and $80 \mu \mathrm{g}$ ipratropium bromide was related to the clinical characteristics of the patients by means of pattern recognition. ${ }^{3}$ With this method the total bronchodilator response after both drugs is $100 \%$ and the response is classified as follows.

Response class 1 More than $75 \%$ of the total response after salbutamol, whatever the order of drug administration.

Response class 2 More than $75 \%$ of the tota response when salbutamol was given first, 25$75 \%$ when it was given second.

Response class 3 From $25 \%$ to $75 \%$ of the total response caused by either salbutamol or ipratropium bromide, whatever the order; or more than $75 \%$ of total response caused by either salbutamol or ipratropium bromide, whichever was given first.

Response class 4 More than $75 \%$ of total response when ipratropium bromide was given first, $25-75 \%$ when it was given second.

Response class 5 More than $75 \%$ of total response caused by ipratropium bromide, whatever the order.

Response patterns were correlated with pulmonary disease (chronic bronchitis or asthma), age, sex, allergy, number of exacerbations, smoking or non-smoking, pack years, symptoms, mean baseline of $\mathrm{FEV}_{1}$, and geometric mean $\mathrm{PC}_{20}$ during the 12 preceding months. $\mathrm{PC}_{20}$ values were logarithmically transformed before analysis. The distribution of the nominal variables was tested by the $\chi^{2}$ test and of the remaining variables by the KruskalWallis test. 

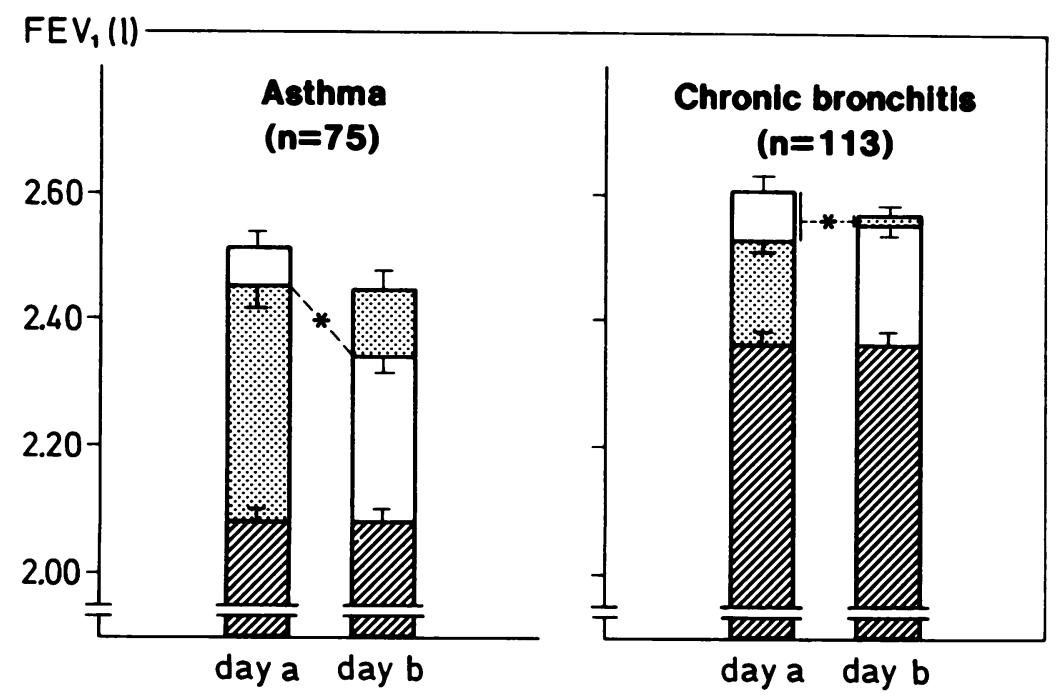

Figure 1 Mean (SEM) baseline FEV, (國) and increases after salbutamol $400 \mu \mathrm{g}$ (圆) and after ipratropium bromide $80 \mu \mathrm{g}(\square)$ for patients with asthma and chronic bronchitis. ${ }^{\star} p<0.05$.
The possibility of tolerance to ipratropium bromide or salbutamol after the 12 month intervention study was investigated in two ways. Firstly, the increases in $\mathrm{FEV}_{1}$ to salbutamol and to ipratropium bromide (given as first drug) in patients who had used these drugs continuously were compared; then the responses in patients who had used one of the drugs symptomatically were compared with the responses in patients who had used the same drug continuously. These differences were tested by means of the non-paired Student's $t$ test. Secondly, a MANOVA procedure was carried out, in which the drug used in the preceding year was the independent variable and the increase in $\mathrm{FEV}_{1}$ to salbutamol or to ipratropium bromide the dependent variable. Asthma versus chronic bronchitis and continuous versus symptomatic treatment were defined as two binary grouping factors. The initial $\mathrm{FEV}_{1}$ (on the first day of the current crossover study) was incorporated as a covariate in this multivariate model.

Table 2 Relation between the response patterns to salbutamol $400 \mu \mathrm{g}$ and to ipratropium bromide $80 \mu \mathrm{g}$ and the clinical characteristics of the patients

\begin{tabular}{|c|c|c|c|c|c|c|}
\hline Response class ${ }^{\star}$ : & & 1 & 2 & 3 & 4 & 5 \\
\hline Number & & 11 & 35 & 74 & 47 & 7 \\
\hline$\%$ Asthmatic patients & + & 64 & 57 & 41 & 30 & 0 \\
\hline Age (years) & & 50 & 53 & 54 & 49 & 60 \\
\hline Sex (\% male) & & 55 & 49 & 57 & 55 & 71 \\
\hline Smokers (\%) & & 91 & 69 & 80 & 87 & 86 \\
\hline Pack years (number) & & 16 & 13 & 16 & 17 & 21 \\
\hline Allergic (\%) & $t$ & 45 & 41 & 22 & 11 & 14 \\
\hline Symptom score & & $5 \cdot 2$ & $5 \cdot 1$ & $4 \cdot 8$ & $5 \cdot 2$ & $4 \cdot 4$ \\
\hline Exacerbations (number) & & $1 \cdot 8$ & 1.5 & $1 \cdot 1$ & $1 \cdot 3$ & $0 \cdot 8$ \\
\hline $\mathrm{FEV}_{1}(1)$ & & $2 \cdot 37$ & $2 \cdot 07$ & $2 \cdot 25$ & $2 \cdot 40$ & $2 \cdot 26$ \\
\hline $\mathrm{FEV}_{1} \%$ pred & & 73 & 68 & 74 & 76 & 76 \\
\hline $\mathrm{FEV}_{1} / \mathrm{IVC}(\%)$ & & 64 & 63 & 66 & 68 & 68 \\
\hline $\mathrm{FEV}_{1} /$ IVC $_{\text {pred }}{ }^{5}$ & & 78 & 76 & 81 & 83 & 85 \\
\hline Geometric mean $\mathrm{PC}_{20}(\mathrm{mg} / \mathrm{ml})$ & & 7 & 12 & 15 & 14 & 20 \\
\hline
\end{tabular}

^Response pattern on a scale beginning with response class 1 (salbutamol $400 \mu \mathrm{g}$ gives a better response- $>75 \%$ of total) and going up to response class 5 (ipratropium bromide $80 \mu \mathrm{g}$ gives a better response). Distributions of variables are compared by the $\chi^{2}$ and Kruskal-Wallis tests. $\dagger$ The distribution of the variable is different from what was expected $(p<0.005)$

$\mathrm{FEV}_{1}$ - forced expiratory volume in one second; IVC-inspiratory vital capacity; $\mathrm{PC}_{20}$ provocative concentration of histamine causing a $20 \%$ fall in $\mathrm{FEV}_{1}$.

\section{Results}

CHANGE IN FEV AFTER SALBUTAMOL AND IPRATROPIUM BROMIDE

Baseline values of $\mathrm{FEV}_{1}$ on day $\mathrm{a}$ and $\mathrm{b}$ differed by less than $3 \%$ (not significant), so a mean baseline value for the two days was calculated. The mean (SD) baseline $\mathrm{FEV}_{1}$ was $2 \cdot 08(0 \cdot 13) 1$ for the asthmatic patients and $2.36(0 \cdot 10) 1$ for the patients with chronic bronchitis. The mean increases in $\mathrm{FEV}_{1}$ after salbutamol $400 \mu \mathrm{g}$ followed by ipratropium bromide $80 \mu \mathrm{g}$ (day a) and after ipratropium bromide $80 \mu \mathrm{g}$ followed by salbutamol $400 \mu \mathrm{g}$ (day b) are shown in figure 1.

The increase in $\mathrm{FEV}_{1}$ in patients with asthma was $0.371(18 \%$ of the prebronchodilator FEV $\left._{1}\right)$ after salbutamol and 0.26 1 (13\%) after ipratropium bromide given as a first drug $(\mathrm{p}<0.05)$. In patients with chronic bronchitis no significant difference was observed between the increases in $\mathrm{FEV}_{1}$ after salbutamol (0.16 l; $7 \%)$ and after ipratropium bromide $(0 \cdot 191$; $8 \%$ ) given as first drug. The additional increase in $\mathrm{FEV}_{1}$ after salbutamol and ipratropium given as the second drug was different in chronic bronchitis $(0.01$ and 0.081 respectively, $\mathrm{p}<0.05)$, but not in asthma $(0.11$ and 0.061$)$.

RESPONSE PATTERNS IN PATIENTS WITH ASTHMA AND CHRONIC BRONCHITIS

The response patterns to salbutamol $400 \mu \mathrm{g}$ and ipratropium bromide $80 \mu \mathrm{g}$ differed in asthma and chronic bronchitis $(p<0.005$; table 2). Asthmatic patients were more likely to respond better to salbutamol than to ipratropium bromide (response classes 1 and 2) and patients with chronic bronchitis were more likely to respond better to ipratropium bromide than to salbutamol (response classes 4 and 5). Seventy four patients ( 30 asthma, 44 chronic bronchitis) had a roughly equal response to the two drugs (response class 3). Fourteen patients had no response to either drug and could not be classified; all had chronic bronchitis.

RESPONSE PATTERNS RELATED TO THE CLINICAL CHARACTERISTICS

The presence of allergy correlated with the response patterns $(p<0.005)$. Patients with a greater response to salbutamol $400 \mu \mathrm{g}$ were more likely to be allergic than patients showing a greater response to ipratropium bromide (table 2). The allergy score also showed a positive linear relation to the response to salbutamol in asthmatic patients $(y=0.032 a+0.314, \mathrm{r}=0.34 ; y=$ increase in FEV (litres), $a=$ allergy score).

Apart from allergy, only age was slightly (but not significantly) correlated with the response patterns $(p<0 \cdot 1)$. The increase in $\mathrm{FEV}_{1}$ after salbutamol $400 \mu \mathrm{g}$ or ipratropium bromide $80 \mu \mathrm{g}$ showed a linear relation to age (fig $2 a-c$ ). The regression coefficient for the effect of ipratropium bromide in asthmatic patients did not deviate significantly from zero. In general (fig 2c), patients under the age of 60 appeared to show a greater increase in $\mathrm{FEV}_{1}$ with sal- 
Figure 2 Increase in $F E V$, after salbutamol $400 \mu \mathrm{g}$ and ipratropium bromide $80 \mu \mathrm{g}$ related to age for

(a) asthmatic patients, (b) patients with chronic bronchitis, and

(c) all patients, with $95 \%$ confidence limits for the regression lines (all $p$ values $<0.005$ ).
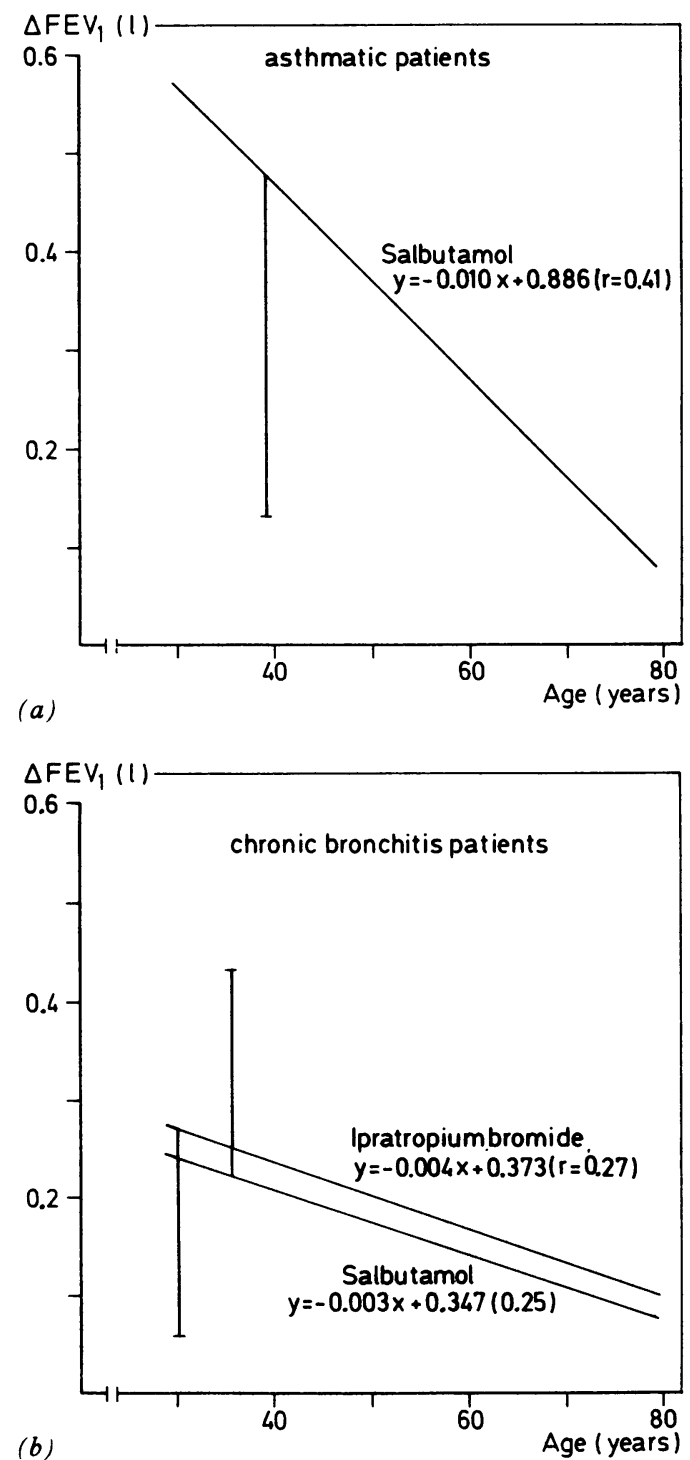

(b)

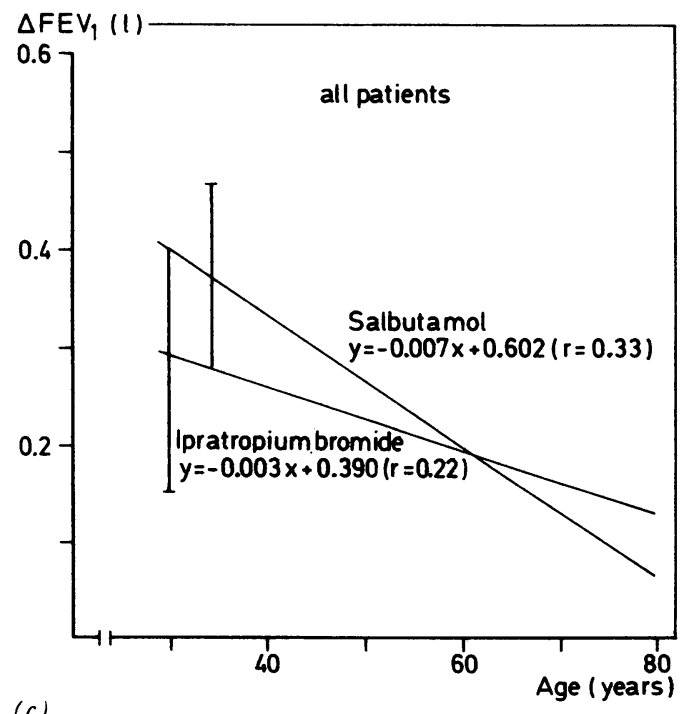

(c)

butamol, whereas patients aged 60 and over benefited more from ipratropium bromide $(\mathrm{p}<0.005)$.

TOLERANCE TO SALBUTAMOL AND IPRATROPIUM BROMIDE

There was no difference in the increase in $\mathrm{FEV}_{1}$ in response to salbutamol or ipratropium bromide between patients who had used one of these drugs in the preceding year and those who had not (table 3 ). Neither the drug (salbutamol versus ipratropium) nor the treatment regimen (continuous versus symptomatic) had a significant influence on the increase in $F E V_{1}$ to salbutamol or to ipratropium bromide.

\section{Discussion}

Most studies have agreed that beta ${ }_{2}$ adrenergic drugs are more efficacious in asthma than anticholinergic drugs when given in conventional clinical doses. ${ }^{31213}$ There is disagreement, however, about the efficacy of both drugs in chronic bronchitis. Several studies have shown that anticholinergic drugs cause the same degree of bronchodilatation as beta adrenergic drugs. ${ }^{21415}$ Other studies report more improvement after anticholinergic drugs. ${ }^{1617}$ Most of these studies concern small, selected groups of patients referred for specialist treatment. In the present study 188 patients from 29 general practices participated. Only patients with moderate airflow obstruction were selected (the mean $\mathrm{FEV}_{1}$ was $74 \%$ predicted) as these patients may be adequately treated with a bronchodilator only. When a $20 \%$ random sample of patients who refused to take part or who were excluded from the initial study was carried out they were found not to differ from the study group with respect to age, sex, smoking behaviour, symptoms, and reversibility of obstruction, ${ }^{4}$ suggesting that no bias had been introduced in the selection procedure. $^{18}$

The present study confirmed that, in general, patients with asthma of moderate severity benefited more from $400 \mu \mathrm{g}$ salbutamol than from $80 \mu \mathrm{g}$ ipratropium bromide, and that patients with chronic bronchitis responded better to $80 \mu \mathrm{g}$ ipratropium bromide than to $400 \mu \mathrm{g}$ salbutamol. In this study we compared conventional clinical doses of ipratropium bromide $80 \mu \mathrm{g}$ and salbutamol $400 \mu \mathrm{g}$. Different doses of salbutamol or ipratropium bromide would have given different results. A recent study in patients with mild asthma showed maximum effects of both salbutamol and ipratropium bromide at doses of $1000 \mu \mathrm{g}$, and equipotency of the two drugs at lower doses. ${ }^{19}$ The dose-response relationships of beta $_{2}$ adrenergic and anticholinergic drugs appear not to have been compared previously in patients with chronic bronchitis.

As the criteria for the diagnosis of asthma and chronic bronchitis vary widely in different countries, it is important to know the criteria used in studies such as ours. ${ }^{20}$ The diagnosis in this study was based on the combination of several "typical features" of chronic bronchitis and asthma, as indicated by the American Thoracic Society. ${ }^{6}$ Patients had to have all the features listed for chronic bronchitis or asthma. If they had one or more features of the other condition in addition they remained in the study, but not if they had all features of both conditions. For examples, $42 \%$ of the patients with a label of chronic bronchitis had a $\mathrm{PC}_{20}$ of 
Table 3 Increase in FEV, after salbutamol $400 \mu \mathrm{g}$ or ipratropium bromide $80 \mu \mathrm{g}$ in relation to treatment in the preceding year (percentages of the mean (SEM) increase compared with initial $F E V_{1}$ )

\begin{tabular}{|c|c|c|c|}
\hline \multirow[b]{2}{*}{ Medication preceding year } & \multirow[b]{2}{*}{$n$} & \multicolumn{2}{|c|}{ Increase in $F E V_{1}(\%)$ after } \\
\hline & & salbutamol & ipratropium \\
\hline \multicolumn{4}{|l|}{ ASTHMA } \\
\hline Ipratropium $4 \times 40 \mu \mathrm{g} /$ day & 17 & $21 \cdot 5(6 \cdot 0)$ & $19 \cdot 4(3 \cdot 0)$ \\
\hline Salbutamol $4 \times 400 \mu \mathrm{g} /$ day & 21 & $24 \cdot 0(3 \cdot 3)$ & $17 \cdot 1(3 \cdot 6)$ \\
\hline Ipratropium symptomatically & 19 & $14 \cdot 3(3 \cdot 0)$ & $12 \cdot 2(2 \cdot 3)$ \\
\hline Salbutamol symptomatically & 18 & $19 \cdot 8(3 \cdot 9)$ & $10 \cdot 3(2 \cdot 9)$ \\
\hline \multicolumn{4}{|l|}{ CHRONIC BRONCHITIS } \\
\hline Ipratropium $4 \times 40 \mu \mathrm{g} /$ day & 26 & $8 \cdot 0(1 \cdot 6)$ & $11 \cdot 2(1 \cdot 7)$ \\
\hline Salbutamol $4 \times 400 \mu \mathrm{g} /$ day & 28 & $10 \cdot 7(2 \cdot 0)$ & $9 \cdot 6(1 \cdot 3)$ \\
\hline Ipratropium symptomatically & 25 & $7 \cdot 5(1.8)$ & $10 \cdot 3(1 \cdot 7)$ \\
\hline Salbutamol symptomatically & 34 & $7 \cdot 2(1 \cdot 5)$ & $5.9(1.4)$ \\
\hline
\end{tabular}

less than $8 \mathrm{mg}$ histamine $/ \mathrm{ml}$ and $18 \%$ were allergic. Among the asthmatic patients $19 \%$ had chronic cough, sputum production, or persistent airways obstruction.

The greater response to ipratropium bromide $80 \mu \mathrm{g}$ than to salbutamol $400 \mu \mathrm{g}$ in the patients with chronic bronchitis might be due to increased parasympathetic tone in the airways. Other factors, such as increased mucociliary clearance ${ }^{21}$ and decreased bronchial secretions, may also play a part.

The greater response of asthmatic patients to salbutamol $400 \mu \mathrm{g}$ may be due to the additional effect of this adrenergic drug on degranulation of the mast cell. ${ }^{1}$ Allergy was one of the discriminating factors in the response to salbutamol versus ipratropium bromide, the response to salbutamol even being related to the allergy score. The large variance in response to salbutamol and ipratropium bromide was partly explained by allergy and partly by age. More than $70 \%$ of the variance, however, remained unexplained. Other factors, such as vagal tone or mucociliary clearance, may be important.

We conclude that patients with mild to moderate airway obstruction vary considerably in their bronchodilating response to salbutamol and ipratropium bromide. In general, salbutamol $400 \mu \mathrm{g}$ gives a better bronchodilating response in asthma, whereas ipratropium bromide $80 \mu \mathrm{g}$ gives a better bronchodilating response in chronic bronchitis. Allergic patients and those under the age of 60 are more likely to benefit from salbutamol; non-allergic patients and patients aged 60 and over are more likely to respond better to ipratropium bromide.

We wish to thank the Dutch Asthma Foundation and
Boehringer Ingelheim Netherlands for their financial support to this study. We are greatly indebted to Mrs L Bierman, Mrs A Raaymakers, and Dr M Peerden for their cooperation in Raaymakers, and Dr $M$ Peerden for their cooperation in measuring the lung function and bronchial reactivity of the patients. We would also like to thank $\mathrm{Mr} \mathrm{H} \mathrm{J} \mathrm{M} \mathrm{van} \mathrm{den} \mathrm{Hoogen}$ for his statistical advice and $\mathrm{Mr} \mathrm{H}$ Bor for his computer

1 Gross NJ, Skorodin MS. Role of the parasympathetic system in airway obstruction due to emphysema. $N$ Engl J Med 1984;311:421-5.

2 Easton PA, Jadue C, Dhingra S, Anthonisen NR. A comparison of the bronchodilating effects of a beta-2 adrenergic agent (albuterol) and an anticholinergic agent (ipratropium bromide), given by aerosol alone or in sequence. $N$ Engl J Med 1986;315:735-9.

3 Ullah MI, Newman GB, Saunders KB. Influence of age on response to ipratropium and salbutamol in asthma. Thorax 1981;36:523-9.

4 Schayck CP van, Weel C van, Folgering H, Verbeek ALM, Herwaarden CLA van. Treatment of patients with airflow obstruction by general practitioners and chest physicians. Scand J Prim Health Care 1989;7:137-42.

5 Quanjer Ph. Standardized lung function testing. Bull Eur Physiopathol Respir 1983;19(suppl 5):7-10.

6 American Thoracic Society. Standards for the diagnosis and care of patients with chronic obstructive pulmonary disease (COPD) and asthma. Am Rev Respir Dis 1987; 136:225-43.

7 Boman G, Bäcker U, Larsson S, Melander B, Wählander L. Oral acetylcysteine-reduces exacerbation rate in chronic bronchitis: report of a trial organized by the Swedish society for pulmonary diseases. Eur J Respir Dis 1983; 64:405-15.

8 Dompeling E, Schayck CP van, Folgering H, Hoogen HJM van den, Weel $C$ van. Accuracy, precision and linearity of the portable flow-volume meter Microspiro HI-298. Eur Respir $J$ (in press).

9 Cockcroft DW, Killian DN, Mellon JJA, Hargreave FE. Bronchial reactivity to inhaled histamine: a method and clinical survey. Clin Allergy 1977; 7:235-9.

10 Lende $R$ van der, Orie NGM. The MRC-ECCS questionnaire on respiratory symptoms (use in epidemiology). Scand J Respir Dis 1972;53:218-26.

11 Wever AMJ, Wever-Hess J, Schayck CP van, Weel C van. Evaluation of the Phadiotop test in an epidemiological study. Allergy 1990;45:92-7.

12 Petrie GR, Palmer KNV. Comparison of aerosol ipratropium bromide and salbutamol in chronic bronchitis and asthma. Br Med J 1975;1:430-2.

13 Ruffin RE, Fitzgerald JD, Rebuck AS. A comparison of the bronchodilator activity of SCH 1000 and salbutamol. $J$ Allergy Clin Immunol 1977;59:136-41.

14 Crompton GK. A comparison of responses to bronchodilator drugs in chronic bronchitis and asthma. Thorax 1968;23:46-55.

15 Leitch AG, Hopkin JM, Ellis DA, Merchant S, McHardy GJR. The effect of aerosol ipratropium bromide and salbutamol on exercise tolerance in chronic bronchitis. Thorax 1978;33:711-3.

16 Douglas NJ, Davidson I, Sudlow MF, Flenley DC. Bronchodilation and the site of airway resistance in severe chronic bronchitis. Thorax 1979;34:51-61.

17 Marini JJ, Lakshminarayan S. Atropine and terbutaline aerosols in chronic bronchitis. Chest 1981;80:285-90.

18 Sundt TM. Was the international trial of extracranialintracranial arterial bypass representative of the population at risk? N Engl J Med 1987;316:814-6.

19 Britton J, Hanley SP, Garrett HV, Hadfield JW, Tattersfield AE. Dose related effects of salbutamol and ipratropium bromide on airway calibre and reactivity in subjects with asthma. Thorax 1988;43:300-5.

20 Pride NB. Definitions of emphysema, chronic bronchitis, asthma, and airflow obstruction: 25 years on from the Ciba symposium. Thorax 1984;39:81-5.

21 Ruffin ME, Wolff RK, Dolovich MB, Rossmann CM, Fitzgerald JD, Newhouse MT. Aerosol therapy with SCH 1000. Short-term mucociliary clearance in normal and bronchitic subjects and toxicology in normal subjects. Chest 1978;73:501-6. 